\section{OPEN ACCESS}

Edited by:

Ravinder Anand-Ivell, University of Nottingham,

United Kingdom

Reviewed by:

Nafis Hasan

Tufts University, United States

Richard Graham Lea,

University of Nottingham,

United Kingdom

*Correspondence:

Arcangelo Barbonett

arcangelo.barbonetti@univaq.it

tThese authors have contributed equally to this work

Specialty section:

This article was submitted to Reproduction,

a section of the journal

Frontiers in Endocrinology

Received: 05 March 2020

Accepted: 05 May 2020

Published: 12 June 2020

Citation:

Castellini C, Totaro M, Parisi $A$ D'Andrea S, Lucente L, Cordeschi G, Francavilla $S$, Francavilla F and Barbonetti A (2020) Bisphenol A and Male Fertility: Myths and Realities.

Front. Endocrinol. 11:353.

doi: 10.3389/fendo.2020.00353

\title{
Bisphenol A and Male Fertility: Myths and Realities
}

\author{
Chiara Castellini ${ }^{\dagger}$, Maria Totaro ${ }^{\dagger}$, Antonio Parisi ${ }^{\dagger}$, Settimio D’Andrea, Liana Lucente, \\ Giuliana Cordeschi, Sandro Francavilla, Felice Francavilla and Arcangelo Barbonetti*
}

Medical Andrology, Department of Life, Health and Environmental Sciences, University of L'Aquila, L'Aquila, Italy

Bisphenol A (BPA) represents the main chemical monomer of epoxy resins and polycarbonate plastics. The environmental presence of BPA is widespread, and it can easily be absorbed by the human body through dietary and transdermal routes, so that more than $90 \%$ of the population in western countries display detectable BPA levels in the urine. As BPA is qualified as an endocrine disruptor, growing concern is rising for possible harmful effects on human health. This review critically discusses the available literature dealing with the possible impact of BPA on male fertility. In rodent models, the in vivo exposure to BPA negatively interfered with the regulation of spermatogenesis throughout the hypothalamic-pituitary-gonadal axis. Furthermore, in in vitro studies, BPA promoted mitochondrial dysfunction and oxidative/apoptotic damages in spermatozoa from different species, including humans. To date, the claimed clinical adverse effects on male fertility are largely based on the results from studies assessing the relationship between urinary BPA concentration and conventional semen parameters. These studies, however, produced controversial evidence due to heterogeneity in the extent of BPA exposure, type of population, and enrollment setting. Moreover, the cause-effect relationship cannot be established due to the cross-sectional design of the studies as well as the large spontaneous between- and within-subject variability of semen parameters. The best evidence of an adverse effect of BPA on male fertility would be provided by prospective studies on clinically relevant endpoints, including natural or medically assisted pregnancies among men either with different exposure degrees (occupational/environmental) or with different clinical conditions (fertile/subfertile).

Keywords: endocrine disruptors, environmental pollution, oxidative stress, spermatozoa, sperm DNA damage

\section{INTRODUCTION}

Bisphenol A (BPA), 4,40-isopropylidenodi-phenol, 2,2-bis(4-hydroxyphenylo)propane, is a crystalline chemical compound widely used as key monomer of epoxy resins and polycarbonate (PC) plastics for more than 50 years (1). The industrial use of BPA is impressive with $\sim 9$ million tons per year produced worldwide (2-4). Resiliency, flexibility, and durability have decreed the large-scale success of BPA-based PC plastics, leading to their use in many and various fields, ranging from the arms industry, for components of safety equipment (helmets), to the manufacture of medical devices, including dental sealants and fillers. In the food industry, synthetic materials containing BPA are widely employed for manufacturing long-term food and drink containers and represent key components of protective coatings, including those covering the internal surface of cans (2-4). A wide variety of other commonly used articles also contain BPA and its derivatives: 
fridges, baby bottles, dishes, lenses, sunglasses, hair dryers, CD and DVD, cell phones, computers, and thermal paper $(1,5,6)$. Owing to its ubiquitous presence, environmental persistence, and the reputation of being an endocrine disruptor, BPA is now regarded as a potential threat to human health, and concerns arise from its possible link with cardiovascular diseases, metabolic disorders, cancer, and infertility (7-10).

The aim of this review is to critically outline and discuss the available literature dealing with the possible impact of BPA on male fertility.

\section{TOXICOKINETICS OF BPA}

BPA is an ideal plasticizer because of its cross-linking characteristics; nevertheless, free monomers can be released into food content after polymerization, especially on exposure to high temperature and with re-use of the containers: this makes possible BPA entering the organism (11-14). As early as 1994, Brotons et al. (15) reported that vegetables preserved in lacquercoated cans acquire estrogenic activity due to contamination by $\mathrm{BPA}$, which is leached from the lacquer coating. More recently, Kubwabo et al. (16) reported that BPA also migrated from the wall of PC baby bottles: high temperatures and prolonged incubation times resulted in increased leaching of BPA, especially when fatty foods were used, whereas BPA leaching from nonPC baby bottles appeared to be negligible under the same experimental conditions (16). Hence, as a precautionary measure, the European Union banned BPA in the production of baby bottles in 2011(2011/8/EU). Resin-based dental filling materials have been feared as another possible source of oral exposure (17). According with two recent systematic reviews, BPA can leach from some resin-based dental materials into the saliva $(18,19)$, reaching detectable urinary concentrations that peak $24 \mathrm{~h}$ after treatment (19). However, the extent to which such an increase may affect the health of patients remains an open question (18).

According to the main regulatory agencies, dietary route represents the primary source of human exposures (2, 20-26) and a tolerable daily intake (TDI) of $50 \mu \mathrm{g} / \mathrm{kg}$ body weight/day has been established, based on studies from rodent models, where clear harmful effects at much higher doses were registered. Based on an analysis of consumer exposure to BPA, the European Food Safety Authority (EFSA) stated that the current levels of exposure are below the TDI (27). Therefore, they would not represent a threat for consumers at any age, taking also into account the short half-life of orally ingested BPA (27).

After ingestion, most of BPA is quickly bound to glucuronic acid by the liver enzyme uridine diphosphonate glucuronosyl transferase (UGT) to produce BPA glucuronide (BPA-G) $(25,28)$. This rapid first-pass liver metabolism makes BPA more soluble in water, with a half-life of elimination in urine of $5.4-6.4 \mathrm{~h}$ $(28,29)$. Therefore, at oral doses ranging from 50 to $100 \mu \mathrm{g} / \mathrm{kg}$ body weight (far above the TDI), in humans, BPA elimination is essentially complete within $24 \mathrm{~h}$, with free BPA accounting for $<1 \%$ of total PBA $(28,29)$. Of note, toxicokinetic processes can be influenced by physiological changes related to pregnancy, as the placenta exhibits beta-glucuronidase enzymatic activity that deconjugates BPA-G $(26,30,31)$. Once having crossed the placental barrier, the BPA conversion to BPA-G in the fetus would be poorly effective, due to the immature liver functions (30).

The highly effective detoxifying system of the human body could counteract possible consequences of a large-scale exposure to BPA. In line with the ubiquitous use of this substance, the reports by the Center for Disease Control and Prevention revealed that more than $90 \%$ of the US population displays detectable BPA levels in urine $(32,33)$. In the largest population study by Calafat et al. (34), detectable levels of total (free plus conjugated) BPA were found in $92.6 \%$ of urine samples from 2,517 participants aged $\geq 6$ years in the 2003-2004 National Health and Nutrition Examination Survey (NHANES). According to a recent study by Gerona et al. (35), these epidemiological data could even be underestimated. Indeed, the results of the largest population studies were produced by using indirect methods requiring the enzymatic hydrolysis of conjugated BPA to free BPA, before its quantification in urine by liquid chromatography-mass spectrometry (LC-MS). Unfortunately, the deconjugation process would be largely incomplete in many cases (35).

Interestingly, when NHANES data were adjusted for the fasting hours preceding the collection of the urinary samples, no clear inverse relationship between fasting hours and urinary BPA levels was found (36). This finding seems to be at the variance with the assumption that BPA is rapidly eliminated after ingestion and that the digestive tract represents the main source of exposure. On the contrary, NHANES data could suggest that either the half-life of BPA is longer than we think or this substance can, to some extent, remain stored in the body or it can even be assimilated through alternative non-dietary routes. Indeed, BPA is also detectable in indoor/outdoor air and floor dust and is widely used in products that come into contact with skin, including not only cosmetics but also thermal paper, where BPA is used as a heat-activated developer $(2,27,37)$. This makes possible its absorption by alternative non-dietary means, such as inhalation and transdermal route. While the estimated inhalation exposure would be negligible when compared to dietary route $(38,39)$, with the exception of some factory workers with high occupational exposure $(40,41)$, transdermal absorption should deserve special attention. Unlike plastics and can linings, where BPA is largely in a polymerized form (PC or PVC), the printing surface of many thermal papers contains milligrams of unbound (free) BPA per gram of paper (42-45), thus explaining the quick transdermal absorption of BPA from this source after handling $(26,45-47)$ : this raises special concerns in individuals who work as cashiers (48). The absorption degree is further enhanced by chemicals which are present in hand sanitizers that can cause a breakdown of the dermal barrier (45). According to EFSA (49), apart from oral exposure, the skin contact with thermal paper represents a major source of exposure to BPA. Of note, while almost all of bloodstream circulating BPA following oral ingestion is in the conjugated form (50-52), after entering the body via a transdermal route, BPA bypasses the liver metabolism, resulting in significantly higher concentrations of unconjugated form in the bloodstream $(50,53-56)$. This is relevant to toxicodynamics because only unconjugated BPA can activate estrogen receptors and is regarded as the biologically active one. 


\section{EFFECTS OF BPA ON MALE FERTILITY Effects on Spermatogenetic Function: Evidence From Preclinical Studies}

In the last decades, results of preclinical research revealed endocrine-disrupting effects of BPA on male reproductive functions, clarifying possible mechanisms by which BPA can interfere with the regulation of spermatogenesis mainly throughout the hypothalamic-pituitary-gonadal axis.

In rodent models, with some exceptions (57-59), the in vivo exposure to BPA at different doses (largely ranging from $2 \mu \mathrm{g} / \mathrm{kg} /$ day to $960 \mathrm{mg} \mathrm{BPA} / \mathrm{kg}$ body weight/day) and time intervals (from 5 to 84 days) resulted in a significant decrease in sperm counts (60-70), sperm motility $(61,62,67)$, normal sperm morphology (62), increase in sperm DNA damage $(63,67)$, and poor spermatogenesis (64-66, 70-72). A large between-studies heterogeneity in both cumulative effective doses and tolerable daily intakes was observed. It might partially be due to differences in susceptibility to BPA effects across rodent species and strains. Genetic factors of animal models can modulate the metabolic rate of a chemical substance, accounting for the variability of its toxicokinetics among the species $(73,74)$. This could determine a variable extent of sensitivity of different species and strains to the same chemical under the same experimental conditions (75).

An interference at hypothalamic-pituitary level of the gonadal axis has been clearly demonstrated in the rat, where, with a few exceptions $(65,76)$, the administration of BPA significantly lowered both the expression of the GnRH gene in cells of preoptic area (64) and circulating levels of gonadotropins and/or testosterone $(64,69,70,77-81)$. Interestingly, the perinatal phase would represent a sensitive exposure window (3), as the treatment of pregnant and nursing dams with BPA decreased intratesticular (77) and circulating (82) testosterone levels of male offspring in adulthood.

BPA is qualified as a xenoestrogen because it mimics estrogen effects due to its characteristic polycyclic phenolic chemical structure, similar to estradiol (77). In a study by Matthews et al. (83), BPA, but not the soluble product of its glucuronidation, was able to displace tritiated $17-\beta$ estradiol from the estrogenic alpha and beta receptors (ER $\alpha$ and $E R \beta$, respectively). The authors observed a more evident dose dependence for $\operatorname{ER} \beta$, to which BPA exhibited higher affinity than to $\mathrm{ER} \alpha$ (83). The affinity for $\mathrm{ER} \alpha$ is 10,000 times lower than that of $17-\beta$ estradiol, more than 20,000 times lower than that of diethylstilbestrol, a synthetic molecule with a powerful estrogenic activity, and 3700 times lower than that of various polychlorinated biphenyls, which represent ubiquitous organic polluting compounds in the environment (84). Despite the low affinity, the binding of BPA to ERs is biologically functional in terms of ERdependent transcription of target genes, as demonstrated by the luciferase reporter gene assay (83). Noteworthy, although BPA acts as a weak estrogen on ERs, it exhibits a very higher affinity (similar to estradiol) for the membrane $G$ protein-coupled estrogen receptor (GPER) of the non-classical estrogenic pathways, mediating rapid non-genomic effects of BPA even at low doses (85). In males, such an estrogenlike endocrine disruption is expected to interfere with the feedback mechanisms of the hypothalamic-pituitary-gonadal axis, leading to a reduced pituitary secretion of gonadotropins and consequent hypostimulation of spermatogenesis and Leydig cell steroidogenesis.

Indeed, the decrease in testosterone levels in animals exposed to BPA could reflect a combination of central (hypothalamicpituitary) and peripheral (testicular) effects. The in vitro treatment of Leydig cells from adult rat with BPA decreased testosterone biosynthesis as a result of decreased expression of steroidogenic enzymes $(77,86)$.

Further possible mechanisms leading to an androgen deficiency status could be sought in the endocrine perturbation exerted by BPA on the differentiation and functions of the adipose tissue. BPA promotes both adipogenesis (87) and lipid storage in adipocytes (88); furthermore, animals treated with low doses of BPA exhibited obesity-related metabolic dysfunctions (89). In this view, BPA is now regarded as a possible environmental obesogen (90). In the complex and bidirectional relationship between obesity and low testosterone, it is welldemonstrated that adipocytes express aromatase activity which is responsible for testosterone conversion into estradiol (91), which can exert a synergistic inhibitory effect on pituitary secretion of luteinizing hormone ( $\mathrm{LH})(92,93)$. An excess of fat mass is also associated with increased levels of circulating leptin which exerts a direct inhibition of Leydig cell steroidogenesis (94, 95). Noteworthily, the chemical structure of BPA is lipophilic; therefore, the effects on adipocytes could be amplified and maintained by its retention in fat mass, establishing a possible vicious circle (96).

BPA can also exert anti-androgenic activity by interfering with the signaling of the androgen receptor (AR) at several levels $(9,69,97)$. BPA acts as a competitive (98) and noncompetitive (99) antagonist of AR and decreases the expression of $\mathrm{AR}$ in the testis (66). Other mechanisms of the antiandrogenic interference include the disruption of the nuclear AR translocation (99) and the enhancement of the interaction of AR with its corepressors, such as the silencing mediator of retinoid and thyroid hormone receptor (SMRT) and the nuclear receptor co-repressor (N-CoR) (100). As spermatogenesis requires both high intratesticular levels of testosterone and an adequate functionality of the $\operatorname{AR}(101,102)$, it is not surprising that the effects of BPA on testosterone biosynthesis and activity could affect spermatogenic function.

Independently of its hormonal disrupting effects, BPA could interfere with spermatogenesis processes even through other mechanisms. After in vivo exposure to BPA, an impaired testicular glucose homeostasis has been reported in the rat (103), and an increased testicular oxidative stress has been revealed both in the rat $(70,103)$ and in the mouse $(104,105)$. BPA can also induce apoptosis in cultured Sertoli cells from rodents (106-109) by inducing dysfunction of mitochondria and generation of reactive oxygen species (ROS) (110). Moreover, an impaired expression of junctional proteins of Sertoli cell has been found in rats that were exposed to BPA neonatally (61), while a downregulated expression of genes involved in Sertoli cell functions has been found in mice that were exposed to BPA prenatally (62). 


\section{Effects on Semen Quality and Reproductive Outcomes: Evidence From Clinical Studies}

Due to the obvious lack of controlled clinical trials investigating the effects of BPA on human male fertility, information is largely inferred from findings of observational epidemiological studies that, with a few exceptions, used semen quality as a surrogate endpoint, producing divergent results likely due to heterogeneity in the extent of BPA exposure, sample sizes, type of population, and enrollment setting (Table 1). Some studies included men from the general population (112-115), others included men attending fertility clinics with (116-120) or without known subfertility (121); one study was restricted to men with proven fertility (122). Only in two studies were men with occupational exposure to BPA included $(111,112)$.

Inconclusive results arise from studies on semen quality in the general population. In a study by Lassen et al. (114) on 308 young men enrolled during physical examinations for military service in Denmark, those in the highest quartile of BPA urinary excretion exhibited significantly lower percentages of progressive sperm motility when compared to the lowest quartile group. Adoamnei et al. (115) reported a significant negative association of urinary BPA concentrations with sperm concentration and total sperm count, but not with motility, in 215 healthy young university students. On the contrary, no significant associations were found between urinary BPA concentrations and any standard semen parameter in the Longitudinal Investigation of Fertility and the Environment (LIFE) study, which recruited 418 men from 16 counties in Michigan and Texas (113).

Also inconclusive are the findings on semen quality arising from studies that enrolled men attending fertility clinics. In a study by Meeker et al. (116), where 190 male partners of couple seeking treatment for infertility were dichotomized as either equal/above or below the reference range for total sperm number, sperm concentration, and sperm motility, according to the WHO 1999 criteria (123), urinary BPA concentration was not associated with a significant odd for having semen parameters below the reference levels. Nevertheless, when variables were modeled continuously in multivariable linear regression models, an increase in urinary BPA levels was associated with a slight, albeit just significant, decrease in the percentage of normal sperm morphology $(p=0.049)$, curvilinear velocity at the computeraided semen analysis $(p=0.04)$ and increased sperm DNA damage $(p=0.048)$ at the comet assay. In a large case-control study by Chen et al. (120), no significant differences were found in urinary BPA concentrations between 877 men with idiopathic infertility and 713 fertile control men. In the same study, crude and multivariable adjusted models did not show significant associations between BPA levels and standard semen parameters (120). In a subsequent study on 149 couples undergoing their first or second in vitro fertilization (IVF) or intracytoplasmic sperm injection (ICSI) procedure, an increased urinary BPA concentration in male partners was associated with lower sperm count, sperm concentration, and sperm vitality (117). However, parameters of embryo development (from the fertilization of oocyte to the stage of blastocyst) were not related to the exposure to BPA (117). In another study on 191 Czech men with infertile marriages, seminal BPA, but not plasma BPA, levels were negatively associated with sperm concentration, sperm count, and, to a lesser extent, normal sperm morphology (118). More recently, Radwan et al. (119) reported that urinary concentration of BPA in 315 men with normal sperm concentration according to the WHO 2010 criteria (124) was negatively associated with sperm motility and positively associated with the percentage of sperm sex chromosome disomy. Finally, in a recent report on a preconception cohort of 161 men without known subfertility, higher urinary BPA concentrations were found in the group of men with abnormal sperm tail morphology, whereas no association was found with sperm count, and no information was provided about other semen parameters (121).

In the Study for Future Families (SFF), the only one enrolling men with proven fertility ( 315 male partners of pregnant women), regression models revealed no relationship between urinary BPA levels and semen parameters (122).

Noteworthy, Li et al. (112) assessed the relationship between urinary BPA levels and semen parameters among 218 factory Chinese workers with or without occupational exposure to BPA. Men with occupational exposure to BPA, who exhibited much higher urinary BPA concentrations, also displayed a significant negative association of BPA with sperm count, viability, and motility. A significant association with lower sperm concentration remained when analysis was restricted to non-occupationally exposed workers. In another study on factory Chinese workers (111), BPA-exposed men $(n=75)$ had significant lower sperm concentration when compared to unexposed group $(n=65)$. Interestingly, authors also found a negative independent association between urinary BPA levels and global methylation degree of sperm DNA, pointing to possible epigenetic consequences of BPA exposure, as already suggested by in vitro studies $(125,126)$.

Actually, two studies assessing more clinically relevant endpoints seem to weaken concerns about the possible adverse impact of BPA exposure on male fertility. In a series from the population-based LIFE study, where Buck-Louis et al. (127) assessed the time to pregnancy in 501 men who were actively trying to conceive, no significant association was found between higher BPA concentrations in the urine and longer duration of pregnancy attempts, after controlling for a number of possible confounders that included partner age. In the cohort of the Environment and Reproductive Health (EARTH) Study, including 218 couples who underwent assisted reproductive technologies (ART) procedures (intrauterine inseminations or IVF), no association was found between paternal urinary BPA concentrations and ART outcomes (128).

\section{Effects on Sperm Functions: Evidence From in vitro Studies}

Experimental studies suggest that BPA could extend its biological effects on male fertility beyond the disrupting effect on the regulation of spermatogenesis, by directly affecting sperm functions. In animal models, the in vitro treatment with different doses of BPA adversely affected sperm motility in fish (129), 
TABLE 1 | Epidemiological studies on the relationship of urinary BPA concentration with semen quality and/or other reproductive outcomes.

\begin{tabular}{|c|c|c|c|c|}
\hline Study & Population & $\begin{array}{l}\text { BPA urinary } \\
\text { concentration: } \\
\text { mean } \pm \text { SD or } \\
\text { median (range) }\end{array}$ & Results & Adjustments \\
\hline $\begin{array}{l}\text { Mendiola } \\
\text { et al. (107) }\end{array}$ & $\begin{array}{l}\text { Fertile men } \\
(n=375)\end{array}$ & $1.5(0.80-3.0) \mu \mathrm{g} / \mathrm{l}^{*}$ & $\begin{array}{l}\text { No significant associations between urinary BPA and semen } \\
\text { parameters. }\end{array}$ & $\begin{array}{l}\text { Age, BMI, smoking status, ethnicity, } \\
\text { center, urinary creatinine } \\
\text { concentration, and time to motility } \\
\text { analysis. }\end{array}$ \\
\hline $\begin{array}{l}\text { Chen et al. } \\
(105)\end{array}$ & $\begin{array}{l}\text { Infertile men } \\
(n=877) \text { and } \\
\text { fertile controls } \\
(n=713)\end{array}$ & $\begin{array}{l}\text { Geometric means: } \\
0.612 \mathrm{ng} / \mathrm{ml} \text { in cases } \\
\text { and } 0.621 \mathrm{ng} / \mathrm{ml} \text { in } \\
\text { controls }\end{array}$ & $\begin{array}{l}\text { No significant associations between urinary BPA levels and } \\
\text { standard semen parameters }\end{array}$ & $\begin{array}{l}\text { Age, BMl, and urinary creatinine } \\
\text { concentration. }\end{array}$ \\
\hline $\begin{array}{l}\text { Buck Luis } \\
\text { et al. (109) }\end{array}$ & $\begin{array}{l}\text { Couples recruited } \\
\text { upon } \\
\text { discontinuing } \\
\text { contraception to } \\
\text { become pregnant } \\
(n=501)\end{array}$ & $1.04(0.91-1.18) \mathrm{ng} / \mathrm{ml}^{*}$ & $\begin{array}{l}\text { BPA concentration was not associated with time to } \\
\text { pregnancy. }\end{array}$ & $\begin{array}{l}\text { Partner age, BMl and urinary } \\
\text { creatinine concentration, female } \\
\text { urinary BPA concentration, smoking, } \\
\text { and center. }\end{array}$ \\
\hline $\begin{array}{l}\text { Knez et al. } \\
(102)\end{array}$ & $\begin{array}{l}\text { Male partners of } \\
\text { couples } \\
\text { seeking infertility } \\
\text { treatment } \\
(n=149)\end{array}$ & $1.55(0.81-3.27) \mathrm{ng} / \mathrm{ml}^{\star}$ & $\begin{array}{l}\text { Urinary BPA was associated with lower total sperm count ( } \beta \\
\text { regression coefficient: }-0.241,95 \% \mathrm{Cl}:-0.47,-0.012) \text {, } \\
\text { sperm concentration ( } \beta \text { regression coefficient: }-0.219,95 \% \\
\mathrm{Cl}:-0.436,-0.003 \text { ), and viability ( } \beta \text { regression coefficient: } \\
-2.66,95 \% \mathrm{Cl}:-4.991,-0.392) \text {. No association between } \\
\text { urinary BPA concentration and embryo development } \\
\text { parameters at IVF/ICSI. }\end{array}$ & $\begin{array}{l}\text { Male age, BMl, current smoking } \\
\text { status, alcohol consumption, } \\
\text { abstinence period, and urinary } \\
\text { creatinine concentration. }\end{array}$ \\
\hline $\begin{array}{l}\text { Miao et al. } \\
(111)\end{array}$ & $\begin{array}{l}\text { Factory workers } \\
\text { with and without } \\
\text { occupational BPA } \\
\text { exposure } \\
(n=140)\end{array}$ & $\begin{array}{l}36.23 \pm 7.69 \mu \mathrm{g} / \mathrm{grCr} \\
\text { in exposed and } \\
1.38 \pm 6.89) \mu \mathrm{g} / \mathrm{grCr} \text { in } \\
\text { non-exposed }\end{array}$ & $\begin{array}{l}\text { Exposed men }(n=75) \text { exhibited a lower sperm concentration } \\
\text { when compared to unexposed group }(n=65): 94.93 \pm \\
58.58 \times 10^{6} / \mathrm{ml} \text { vs. } 126.42 \pm 82.26 \times 10^{6} / \mathrm{ml}(p=0.03) \text {. } \\
\text { Higher urinary BPA levels were independently associated with } \\
\text { lower global methylation degree of sperm DNA. }\end{array}$ & $\begin{array}{l}\text { Age, education, history of disease, } \\
\text { smoking, and alcohol consumption }\end{array}$ \\
\hline $\begin{array}{l}\text { Dodge et al. } \\
\text { (110) }\end{array}$ & $\begin{array}{l}\text { Couples seeking } \\
\text { infertility } \\
\text { treatments } \\
(n=218)\end{array}$ & $1.6(0.8-2.8) \mathrm{ng} / \mathrm{ml}$ & $\begin{array}{l}\text { Lower male BPA concentrations were associated with a } \\
\text { greater proportion of high-quality embryos in IVF cycles (RR } \\
=1.92 ; 95 \% \mathrm{Cl}: 1.13,3.25) \text {. }\end{array}$ & $\begin{array}{l}\text { Maternal age, paternal normal weight, } \\
\text { maternal normal weight, and maternal } \\
\text { smoking. }\end{array}$ \\
\hline $\begin{array}{l}\text { Goldstone } \\
\text { et al. (98) }\end{array}$ & $\begin{array}{l}\text { Male partners of } \\
\text { couples who } \\
\text { discontinued } \\
\text { contraception to } \\
\text { become pregnant } \\
(n=418)\end{array}$ & $\begin{array}{l}0.51(0.46-0.58) \\
\mu \mathrm{g} / \mathrm{grCr}^{*}\end{array}$ & $\begin{array}{l}\text { No significant association was found between urinary BPA } \\
\text { levels and any standard semen parameter. }\end{array}$ & $\begin{array}{l}\text { Age, abstinence time, alcohol } \\
\text { consumption, BMI, smoking, } \\
\text { previously fathered pregnancy, center, } \\
\text { and ethnicity. }\end{array}$ \\
\hline $\begin{array}{l}\text { Vitku et al. } \\
\text { (103) }\end{array}$ & $\begin{array}{l}\text { Male partners in } \\
\text { couples seeking } \\
\text { infertility treatment } \\
(n=191)\end{array}$ & $\begin{array}{l}0.075(0.055-0.100) \\
\mathrm{ng} / \mathrm{ml}^{\#}\end{array}$ & $\begin{array}{l}\text { Seminal BPA but not plasma BPA was negatively associated } \\
\text { with sperm count }\left(r^{\S}=-0.178 ; p=0.018\right) \text {, concentration }\left(r^{\S}\right. \\
=-0.198 ; p=0.009) \text {, and morphology }\left(r^{\S}=-0.160 ;\right. \\
p=0.044)\end{array}$ & Age, BMl, and abstinence time. \\
\hline
\end{tabular}


TABLE 1 | Continued

\begin{tabular}{|c|c|c|c|c|}
\hline Study & Population & $\begin{array}{l}\text { BPA urinary } \\
\text { concentration: } \\
\text { mean } \pm \text { SD or } \\
\text { median (range) }\end{array}$ & Results & Adjustments \\
\hline $\begin{array}{l}\text { Adoamnei } \\
\text { et al. (100) }\end{array}$ & $\begin{array}{l}\text { Healthy young } \\
\text { university students } \\
(n=215)\end{array}$ & $\begin{array}{l}1.8(0.14-11.9) \\
\mu \mathrm{g} / \mathrm{grCr}^{*}\end{array}$ & $\begin{array}{l}\text { Urinary BPA concentration was negatively associated with } \\
\text { sperm concentration ( } \beta \text { regression coefficient }=-0.04,95 \% \\
\mathrm{Cl}:-0.07 ;-0.02) \text { and total sperm count }(\beta \text { regression } \\
\text { coefficient }=-0.05,95 \% \mathrm{Cl}:-0.08 ;-0.02) \text {. }\end{array}$ & $\begin{array}{l}\text { BMI, smoking, varicocele, abstinence } \\
\text { time, and time to motility analysis. }\end{array}$ \\
\hline $\begin{array}{l}\text { Pollard et al. } \\
\text { (106) }\end{array}$ & $\begin{array}{l}\text { Male partners in } \\
\text { couples seeking to } \\
\text { become pregnant } \\
\text { without history of } \\
\text { infertility ( } n=161)\end{array}$ & $2.5 \mathrm{ng}_{\mathrm{ml}}{ }^{\dagger}$ & $\begin{array}{l}\text { Higher urinary BPA concentrations were associated with } \\
\text { increased percentage of sperm with abnormal tail } \\
\text { morphology }(p=0.032)\end{array}$ & $\begin{array}{l}\text { Age, ethnicity, income, smoking, and } \\
\text { BMI. }\end{array}$ \\
\hline
\end{tabular}

BMI, body mass index; BPA, bisphenol A; Cl, confidence intervals; ICSI, intracytoplasmic sperm injection; IVF, in vitro fertilization; RR, rate ratio; VCL, curvilinear velocity. *values are mean (25th-75th percentiles); " seminal BPA levels; ${ }^{{ }^{r}} r=$ correlation coefficient of partial correlation; ${ }^{\dagger}$ geometric mean.

bovine (130), mouse (131), and chicken (132) and also impaired sperm fertilizing ability in mouse (131) and chicken (132). Consistent with data from in vitro studies on several types of cells (106-108, 133-137), these effects could be mediated by oxidative-apoptotic mechanisms: it has been reported that the exposure to BPA reduces mitochondrial membrane potential $(\Delta \Psi \mathrm{m})$ in chicken spermatozoa (132) and promotes ROS generation in bovine spermatozoa (130); oxidative stress and high DNA fragmentation have been also reported in fish spermatozoa exposed to BPA (129). To date, only two studies have assessed the direct in vitro effects of BPA on human spermatozoa. In the first study, which was carried out from our group (138), the exposure of motile spermatozoa to scalar concentrations of BPA $(10-800 \mu \mathrm{M})$ for $4 \mathrm{~h}$ produced a decrease in $\Delta \Psi \mathrm{m}$, starting from $300 \mu \mathrm{M}$, which was accompanied by mitochondrial superoxide anion generation, activation of caspase- 9 and caspase-3, and motility decrease. As a late consequence of oxidative stress, a 20-h exposure to $300 \mu \mathrm{M}$ BPA (but not to lower doses) also produced a significant decrease in sperm viability, complete sperm immobilization, and oxidative damage of DNA, as revealed by the generation of the oxidized base adduct 8hydroxy-2'-deoxyguanosine (138). An inhibitory effect on $\Delta \Psi \mathrm{m}$ in human spermatozoa exposed to BPA has been also reported, even at very lower doses, in a subsequent study by Grami et al. (139).

\section{DISCUSSION}

Due to the widespread presence of BPA, environmental exposure to this chemical spares no one: large epidemiological studies revealed that more than $90 \%$ of the population in western countries displays detectable BPA in the urine (32-34) and toxicokinetic analyses pointed to dietary and transdermal routes as the primary sources of human exposure.
As BPA is qualified as a xenoestrogen endocrine disruptor, growing concern is rising for possible harmful effects on human health, including fertility. Indeed, except for some factory workers with high occupational exposure, measured BPA levels in biological fluids are usually low and the hazards to fertility for the general population remain a matter for debate.

Overall, while preclinical studies have clearly shown that BPA can negatively interfere with the regulation of spermatogenesis, as well as with sperm functions, the claimed clinical adverse effects on male fertility are largely based on the results from conventional semen analysis, that, however, produced controversial evidence (Table 1), being strongly weakened by a number of limitations. Firstly, the cross-sectional design of the studies and the large spontaneous between- and within-subject variability of semen parameters (140) hinder any conclusion about the cause-effect relationships. Although analyses were adjusted for a number of possible confounding factors, it cannot be excluded that other unmeasured confounders have not influenced the examined associations. Other endocrinedisrupting substances are ubiquitous in the environment and may coexist in the human body, leading to possible synergic effects on semen quality with BPA not necessarily playing the major role. Secondly, heterogeneity arises from the inclusion of different study populations with variable degrees of exposure to BPA and, probably, from the variable susceptibility to its effects: in fertile men with low unintentional environmental BPA exposure, any detectable effect on reproductive functions is likely to be small, with uncertain clinical significance. Whether or not low unintentional environmental BPA exposure can worsen the fertility potential in subfertile men would represent a more relevant issue, but it is difficult to be ascertained. On the other hand, when men with or without occupational exposure to BPA were compared, those with 
occupational exposure, who exhibited much higher urinary BPA concentrations, also displayed a significant negative association of BPA with sperm count $(111,112)$, viability, and motility (112). Further studies on occupationally exposed workers are warranted.

The best evidence of an adverse effect of BPA on male fertility would be provided by prospective studies on clinically relevant endpoints, including natural or medically assisted pregnancies among men either with different exposure degrees (occupational/environmental) or with different clinical conditions (fertile/subfertile). However, this is a hard challenge.

\section{REFERENCES}

1. Tomza-Marciniak A, Stepkowska P, Kuba J, Pilarczyk B. Effect of bisphenol a on reproductive processes: a review of in vitro, in vivo and epidemiological studies. J Appl Toxicol. (2018) 38:51-80. doi: 10.1002/jat.3480

2. Vandenberg LN, Hauser R, Marcus $M$, Olea $N$, Welshons WV. Human exposure to bisphenol a (BPA). Reprod Toxicol. (2007) 24:139-77. doi: 10.1016/j.reprotox.2007.07.010

3. Vandenberg LN, Maffini MV, Sonnenschein C, Rubin BS, Soto AM. Bisphenol-A and the great divide: a review of controversies in the field of endocrine disruption. Endocr Rev. (2009) 30:75-95. doi: 10.1210/er.2008-0021

4. Peretz J, Vrooman L, Ricke WA, Hunt PA, Ehrlich S, Hauser R, et al. Bisphenol a and reproductive health: update of experimental and human evidence, 2007-2013. Environ Health Perspect. (2014) 122:77586. doi: 10.1289/ehp. 1307728

5. Östberg T, Noaksson E. Bisfenol a in svenska kvitton. Analysresultat. Institutet för Tillämoa Grön Kemi, Jämtlands läns Landstingb (2010).

6. European Food Safety Authority (EFSA). Public consultation on the draft opinion on bisphenol A (BPA) - exposure assessment. (2013). p. 314.

7. Lang IA, Galloway TS, Scarlett A, Henley WE, Depledge M, Wallace $\mathrm{RB}$, et al. Association of urinary bisphenol a concentration with medical disorders and laboratory abnormalities in adults. JAMA. (2008) 300:130310. doi: 10.1001/jama.300.11.1303

8. Jenkins S, Wang J, Eltoum I, Desmond R, Lamartiniere CA. Chronic oral exposure to bisphenol a results in a nonmonotonic dose response in mammary carcinogenesis and metastasis in MMTV-erbB2 mice. Environ Health Perspect. (2011) 119:1604-09. doi: 10.1289/ehp.1103850

9. Rochester JR. Bisphenol A and human health: a review of the literature. Reprod Toxicol. (2013) 42:132-55. doi: 10.1016/j.reprotox.2013.08.008

10. Cariati F, D’Uonno N, Borrillo F, Iervolino S, Galdiero G, Tomaiuolo R. "Bisphenol a: an emerging threat to male fertility". Reprod Biol Endocrinol. (2019) 17:6. doi: 10.1186/s12958-018-0447-6

11. Tan BL, Mustafa AM. Leaching of bisphenol a from new and old babies' bottles, and new babies' feeding teats. Asia Pac J Public Health. (2003) 15:118-23. doi: 10.1177/101053950301500208

12. López-Cervantes J, Paseiro-Losada P. Determination of bisphenol a in, and its migration from, PVC stretch film used for food packaging. Food Addit Contam. (2003) 20:596-606. doi: 10.1080/0265203031000109495

13. Fernandez MF, Arrebola JP, Taoufiki J, Navalón A, Ballesteros O, Pulgar R, et al. Bisphenol-A and chlorinated derivatives in adipose tissue of women. Reprod Toxicol. (2007) 24:259-64. doi: 10.1016/j.reprotox.2007.06.007

14. Le HH, Carlson EM, Chua JP, Belcher SM. Bisphenol A is released from polycarbonate drinking bottles and mimics the neurotoxic actions of estrogen in developing cerebellar neurons. Toxicol Lett. (2008) 176:14956. doi: 10.1016/j.toxlet.2007.11.001

15. Brotons JA, Olea-Serrano MF, Villalobos M, Olea N. Xenoestrogens released from lacquer coating in food cans. Environ Health Perspect. (1994) 103:60812. doi: $10.1289 /$ ehp.95103608

16. Kubwabo C, Kosarac I, Stewart B, Gauthier BR, Lalonde K, Lalonde PJ. Migration of bisphenol A from plastic baby bottles, baby bottle

\section{AUTHOR CONTRIBUTIONS}

$\mathrm{AB}$ and FF contributed conception and design of the study. CC, $\mathrm{MT}$, and AP performed the literature search and wrote sections of the manuscript. SD'A, LL, and GC contributed literature search. $\mathrm{AB}$ wrote the first draft of the manuscript. SF, FF, and AB critically revised the manuscript. All authors contributed to manuscript revision, read and approved the submitted version.

\section{FUNDING}

Supported by a grant to SF: PRIN 2017, MIUR, Italy.

liners and reusable polycarbonate drinking bottles. C Food Addit Contam Part A Chem Anal Control Expo Risk Assess. (2009) 26:92837. doi: 10.1080/02652030802706725

17. Olea N, Pulgar R, Pérez P, Olea-Serrano F, Rivas A, Novillo-Fertrell A, et al. Estrogenicity of resin-based composites and sealants used in dentistry. Environ Health Perspect. (1996) 104:298-305. doi: 10.1289/ehp.96104298

18. Löfroth M, Ghasemimehr M, Falk A, Vult von Steyern P. Bisphenol A in dental materials - existence, leakage and biological effects. Heliyon. (2019) 5:e01711. doi: 10.1016/j.heliyon.2019.e01711

19. Marzouk T, Sathyanarayana S, Kim AS, Seminario AL, McKinney CM. A systematic review of exposure to bisphenol a from dental treatment. JDR Clin Trans Res. (2019) 4:106-15. doi: 10.1177/2380084418816079

20. Kang JH, Kondo F, Katayama Y. Human exposure to bisphenol A. Toxicology. (2006) 226:79-89. doi: 10.1016/j.tox.2006.06.009

21. European Food Safety Authority (EFSA). Opinion of the Scientific Panel on Food Additives, Flavourings, Processing Aids and Materials in Contact with Food on a request from the Commission related to 2,2-BIS(4HYDROXYPHENYL)PROPANE (Bisphenol A). EFSA J. (2006) 19-23. 428. doi: 10.2903/j.efsa.2007.428

22. Chapin RE, Adams J, Boekelheide K, Gray LE Jr, Hayward SW, Lees PS, et al. NTP-CERHR expert panel report on the reproductive and developmental toxicity of bisphenol A. Birth Defects Res B Dev Reprod Toxicol. (2008) 83:157-395. doi: 10.1002/bdrb.20147

23. Vandenberg LN, Hunt PA, Myers JP, Vom Saal FS. Human exposures to bisphenol A: mismatches between data and assumptions. Rev Environ Health. (2013) 28:37-58. doi: 10.1515/reveh-2012-0034

24. FAO/WHO. Joint Food and Agriculture Organization of the United Nations and World Health Organization (FAO/WHO) Expert Meeting to Review Toxicological and Health Aspects of Bisphenol A: Final Report, Including Report of Stakeholder Meeting on Bisphenol A; 1-5 November 2010. Ottawa: FAO and WHO (2011).

25. Shelby MD. NTP-CERHR monograph on the potential human reproductive and developmental effects of bisphenol A. NTP CERHR MON. (2008) v:viiix, 1-64 passim.

26. Geens T, Goeyens L, Kannan K, Neels H, Covaci A. Levels of bisphenol A in thermal paper receipts from Belgium and estimation of human exposure. Sci Total Environ. (2012) 435-36:30-3. doi: 10.1016/j.scitotenv.2012.07.001

27. European Food Safety Authority (EFSA). Scientific Opinion on the Risks to Public Health Related to the Presence of Bisphenol A (BPA) in Foodstuffs: Executive Summary, 1st ed. Parma: European Food Safety Authority (2015).

28. Thayer KA, Doerge DR, Hunt D, Schurman SH, Twaddle NC, Churchwell MI, et al. Pharmacokinetics of bisphenol A in humans following a single oral administration. Environ Int. (2015) 83:107-15. doi: 10.1016/j.envint.2015.06.008

29. Völkel W, Colnot T, Csanády GA, Filser JG, Dekant W. Metabolism and kinetics of bisphenol a in humans at low doses following oral administration. Chem Res Toxicol. (2002) 15:1281-7. doi: 10.1021/tx025548t

30. Ikezuki Y, Tsutsumi O, Takai Y, Kamai Y, Taketani Y. Determination of bisphenol A concentrations in human biological fluids reveals significant early prenatal exposure. Hum Reprod. (2002) 17:2839-41. doi: 10.1093/humrep/17.11.2839 
31. Zhang J, Cooke GM, Curran IH, Goodyer CG, Cao XL. GC-MS analysis of bisphenol A in human placental and fetal liver samples. J Chromatogr B Analyt Technol Biomed Life Sci. (2011) 879:20914. doi: 10.1016/j.jchromb.2010.11.031

32. Department of Health and Human Services Centers for Disease Control and Prevention National Center for Environmental Health Division of Laboratory Sciences. Fourth National Report on Human Exposure to Environmental Chemicals, Georgia (2009).

33. Department of Health and Human Services Centers for Disease Control and Prevention National Center for Environmental Health Division of Laboratory Sciences. Fourth National Report on Human Exposure to Environmental Chemicals Updated Tables, Georgia (2018).

34. Calafat AM, Ye X, Wong LY, Reidy JA, Needham LL. Exposure of the U.S. population to bisphenol A and 4-tertiary-octylphenol: 2003-2004. Environ Health Perspect. (2008) 116:39-44. doi: 10.1289/ehp.10753

35. Gerona R, Vom Saal FS, Hunt PA. BPA: have flawed analytical techniques compromised risk assessments? Lancet Diabetes Endocrinol. (2020) 8:113. doi: 10.1016/S2213-8587(19)30381-X

36. Stahlhut RW, Welshons WV, Swan SH. Bisphenol A data in NHANES suggest longer than expected half-life, substantial nonfood exposure, or both. Environ Health Perspect. (2009) 117:784-9. doi: 10.1289/ehp.0800376

37. Dodson RE, Nishioka M, Standley LJ, Perovich LJ, Brody JG, Rudel RA. Endocrine disruptors and asthma-associated chemicals in consumer products. Environ Health Perspect. (2012) 120:935-43. doi: 10.1289/ehp.1104052

38. Wilson NK, Chuang JC, Lyu C, Menton R, Morgan MK. Aggregate exposures of nine preschool children to persistent organic pollutants at day care and at home. J Expo Anal Environ Epidemiol. (2003) 13:187202. doi: $10.1038 /$ sj.jea. 7500270

39. Wilson NK, Chuang JC, Morgan MK, Lordo RA, Sheldon LS. An observational study of the potential exposures of preschool children to pentachlorophenol, bisphenol-A, and nonylphenol at home and daycare. Environ Res. (2007) 103:9. doi: 10.1016/j.envres.2006.04.006

40. Heinälä M, Ylinen K, Tuomi T, Santonen T, Porras SP. Assessment of occupational exposure to bisphenol a in five different production companies in Finland. Ann Work Expo Health. (2017) 61:44-55. doi: 10.1093/annweh/wxw006

41. Hines CJ, Christianson AL, Jackson MV, Ye X, Pretty JR, Arnold JE, et al. An evaluation of the relationship among urine, air, and hand measures of exposure to bisphenol a (BPA) in US manufacturing workers. Ann Work Expo Health. (2018) 62:840-51. doi: 10.1093/annweh/wxy042

42. Biedermann S, Tschudin P, Grob K. Transfer of bisphenol A from thermal printer paper to the skin. Anal Bioanal Chem. (2010) 398:5716. doi: 10.1007/s00216-010-3936-9

43. Liao C, Liu F, Kannan K. Bisphenol s, a new bisphenol analogue, in paper products and currency bills and its association with bisphenol a residues. Environ Sci Technol. (2012) 46:6515-22. doi: 10.1021/es300876n

44. Liao C, Kannan K. Widespread occurrence of bisphenol A in paper and paper products: implications for human exposure. Environ Sci Technol. (2011) 45:9372-9. doi: 10.1021/es202507f

45. Hormann AM, Vom Saal FS, Nagel SC, Stahlhut RW, Moyer CL, Ellersieck $\mathrm{MR}$, et al. Holding thermal receipt paper and eating food after using hand sanitizer results in high serum bioactive and urine total levels of bisphenol A (BPA). PLoS ONE. (2014) 9:e110509. doi: 10.1371/journal.pone.0110509

46. Terasaki M, Shiraishi F, Fukazawa H, Makino M. Occurrence and estrogenicity of phenolics in paper-recycling process water: pollutants originating from thermal paper in waste paper. Environ Toxicol Chem. (2007) 26:2356-66. doi: 10.1897/06-642

47. Geens T, Goeyens L, Covaci A. Are potential sources for human exposure to bisphenol-A overlooked? Int J Hyg Environ Health. (2011) 214:33947. doi: 10.1016/j.ijheh.2011.04.005

48. Braun JM, Kalkbrenner AE, Calafat AM, Bernert JT, Ye X, Silva $\mathrm{MJ}$, et al. Variability and predictors of urinary bisphenol A concentrations during pregnancy. Environ Health Perspect. (2011) 119:131-7. doi: 10.1289/ehp.1002366

49. Porras SP, Heinälä M, Santonen T. Bisphenol A exposure via thermal paper receipts. Toxicol Lett. (2014) 230:413-20. doi: 10.1016/j.toxlet.2014.08.020

50. Pottenger LH, Domoradzki JY, Markham DA, Hansen SC, Cagen SZ, Waechter JM Jr. The relative bioavailability and metabolism of bisphenol A in rats is dependent upon the route of administration. Toxicol Sci. (2000) 54:3-18. doi: 10.1093/toxsci/54.1.3

51. Zalko D, Soto AM, Dolo L, Dorio C, Ratahao E, Debrauwer L, et al. Biotransformations of bisphenol A in a mammalian model: answers and new questions raised by low-dose metabolic fate studies in pregnant CD1 mice. Environ Health Perspect. (2003) 111:309-19. doi: 10.1289/ehp.5603

52. Domoradzki JY, Pottenger LH, Thornton CM, Hansen SC, Card TL, Markham DA, et al. Metabolism and pharmacokinetics of bisphenol A (BPA) and the embryo-fetal distribution of BPA and BPA-monoglucuronide in CD Sprague-Dawley rats at three gestational stages. Toxicol Sci. (2003) 76:21-34. doi: 10.1093/toxsci/kfg206

53. Negishi T, Tominaga T, Ishii Y, Kyuwa S, Hayasaka I, Kuroda Y, et al. Comparative study on toxicokinetics of bisphenol A in F344 rats, monkeys (Macaca fascicularis), and chimpanzees (Pan troglodytes). Exp Anim. (2004) 53:391-4. doi: 10.1538/expanim.53.391

54. Tominaga T, Negishi T, Hirooka H, Miyachi A, Inoue A, Hayasaka $\mathrm{I}$, et al. Toxicokinetics of bisphenol $\mathrm{A}$ in rats, monkeys and chimpanzees by the LC-MS/MS method. Toxicology. (2006) 226:208-17. doi: 10.1016/j.tox.2006.07.004

55. Lv Y, Lu S, Dai Y, Rui C, Wang Y, Zhou Y, et al. Higher dermal exposure of cashiers to BPA and its association with DNA oxidative damage. Environ Int. (2017) 98:69-74. doi: 10.1016/j.envint.2016.10.001

56. Lee I, Kim S, Kim KT, Kim S, Park S, Lee H, et al. Bisphenol A exposure through receipt handling and its association with insulin resistance among female cashiers. Environ Int. (2018) 117:268-75. doi: 10.1016/j.envint.2018.05.013

57. Tyl RW, Myers CB, Marr MC, Sloan CS, Castillo NP, Veselica MM, et al. Two-generation reproductive toxicity study of dietary bisphenol A in CD-1 (Swiss) mice. Toxicol Sci. (2008) 104:362-84. doi: 10.1093/toxsci/kfn084

58. Kobayashi K, Ohtani K, Kubota H, Miyagawa M. Dietary exposure to low doses of bisphenol A: effects on reproduction and development in two generations of C57BL/6J mice. Congenit Anom. (2010) 50:15970. doi: 10.1111/j.1741-4520.2010.00279.x

59. LaRocca J, Boyajian A, Brown C, Smith SD, Hixon M. Effects of in utero exposure to Bisphenol A or diethylstilbestrol on the adult male reproductive system. Birth Defects Res B Dev Reprod Toxicol. (2011) 92:52633. doi: 10.1002/bdrb.20336

60. Al-Hiyasat AS, Darmani H, Elbetieha AM. Effects of bisphenol A on adult male mouse fertility. Eur J Oral Sci. (2002) 110:163-7. doi: 10.1034/j.1600-0722.2002.11201.x

61. Salian S, Doshi T, Vanage G. Neonatal exposure of male rats to Bisphenol A impairs fertility and expression of sertoli cell junctional proteins in the testis. Toxicology. (2009) 265:56-67. doi: 10.1016/j.tox.2009.09.012

62. Tainaka H, Takahashi H, Umezawa M, Tanaka H, Nishimune Y, Oshio S, et al. Evaluation of the testicular toxicity of prenatal exposure to bisphenol A based on microarray analysis combined with MeSH annotation. J Toxicol Sci. (2012) 37:539-48. doi: 10.2131/jts.37.539

63. Dobrzynska MM, Radzikowska J. Genotoxicity and reproductive toxicity of bisphenol A and X-ray/bisphenol A combination in male mice. Drug Chem Toxicol. (2013) 36:19-26. doi: 10.3109/01480545.2011.644561

64. Jin P, Wang X, Chang F, Bai Y, Li Y, Zhou R, et al. Low dose bisphenol A impairs spermatogenesis by suppressing reproductive hormone production and promoting germ cell apoptosis in adult rats. J Biomed Res. (2013) 27:135-44. doi: 10.7555/JBR.27.20120076

65. Liu C, Duan W, Li R, Xu S, Zhang L, Chen C, et al. Exposure to bisphenol A disrupts meiotic progression during spermatogenesis in adult rats through estrogen-like activity. Cell Death Dis. (2013) 4:e676. doi: 10.1038/cddis.2013.203

66. Qiu LL, Wang X, Zhang XH, Zhang Z, Gu J, Liu L, et al. Decreased androgen receptor expression may contribute to spermatogenesis failure in rats exposed to low concentration of bisphenol A. Toxicol Lett. (2013) 219:116-24. doi: 10.1016/j.toxlet.2013.03.011

67. Tiwari D, Vanage G. Mutagenic effect of bisphenol A on adult rat male germ cells and their fertility. Reprod Toxicol. (2013) 40:608. doi: 10.1016/j.reprotox.2013.05.013

68. Kourouma A, Peng D, Chao Q, Lopez YM, Changjiang L, Chengmin W, et al. Bisphenol A induced reactive oxygen species (ROS) in the liver and affect epididymal semen quality in adults sprague-dawley rats. J Toxicol Env Health Sci. (2014) 6:103-12. doi: 10.5897/JTEHS2014.0309 
69. Wisniewski P, Romano RM, Kizys MM, Oliveira KC, Kasamatsu T, Giannocco G, et al. Adult exposure to bisphenol A (BPA) in Wistar rats reduces sperm quality with disruption of the hypothalamic-pituitarytesticular axis. Toxicology. (2015) 329:1-9. doi: 10.1016/j.tox.2015.01.002

70. Grami D, Rtibi K, Hammami I, Selmi S, De Toni L, Foresta C, et al. Protective action of eruca sativa leaves aqueous extracts against bisphenol a-caused in vivo testicular damages. J Med Food. (2019) 23:60010. doi: 10.1089/jmf.2019.0170

71. Li YJ, Song TB, Cai YY, Zhou JS, Song X, Zhao X, et al. Bisphenol A exposure induces apoptosis and upregulation of Fas/FasL and caspase- 3 expression in the testes of mice. Toxicol Sci. (2009) 108:427-36. doi: 10.1093/toxsci/kfp024

72. Kazemi S, Bahramifar N, Moghadamnia AA, Jorsarae SG. Detection of bisphenol a and nonylphenol in rat's blood serum, tissue and impact on reproductive system. Electron Physician. (2016) 8:277280. doi: $10.19082 / 2772$

73. Spearow JL, Doemeny P, Sera R, Leffler R, Barkley M. Genetic variation in susceptibility to endocrine disruption by estrogen in mice. Science. (1999) 285:1259-61. doi: 10.1126/science.285.5431.1259

74. Goodman JE, McConnell EE, Sipes IG, Witorsch RJ, Slayton TM, Yu CJ, et al. An updated weight of the evidence evaluation of reproductive and developmental effects of low doses of bisphenol A. Crit Rev Toxicol. (2006) 36:387-457. doi: 10.1080/10408440600758317

75. Wadia PR, Vandenberg LN, Schaeberle CM, Rubin BS, Sonnenschein C, Soto AM. Perinatal bisphenol A exposure increases estrogen sensitivity of the mammary gland in diverse mouse strains. Environ Health Perspect. (2007) 115:592-8. doi: 10.1289/ehp.9640

76. Kobayashi K, Kubota H, Ohtani K, Hojo R, Miyagawa M. Lack of effects for dietary exposure of bisphenol A during in utero and lactational periods on reproductive development in rat offspring. J Toxicol Sci. (2012) 37:56573. doi: $10.2131 /$ jts. 37.565

77. Akingbemi BT, Sottas CM, Koulova AI, Klinefelter GR, Hardy MP. Inhibition of testicular steroidogenesis by the xenoestrogen bisphenol $\mathrm{A}$ is associated with reduced pituitary luteinizing hormone secretion and decreased steroidogenic enzyme gene expression in rat leydig cells. Endocrinology. (2004) 145:592-603. doi: 10.1210/en.2003-1174

78. Salian S, Doshi T, Vanage G. Perinatal exposure of rats to bisphenol A affects the fertility of male offspring. Life Sci. (2009) 85:74252. doi: 10.1016/j.lfs.2009.10.004

79. Nakamura D, Yanagiba Y, Duan Z, Ito Y, Okamura A, Asaeda N, et al. Bisphenol A may cause testosterone reduction by adversely affecting both testis and pituitary systems similar to estradiol. Toxicol Lett. (2010) 194:1625. doi: 10.1016/j.toxlet.2010.02.002

80. Castro B, Sánchez P, Torres JM, Preda O, del Moral RG, Ortega E. Bisphenol A exposure during adulthood alters expression of aromatase and $5 \alpha$-reductase isozymes in rat prostate. PLoS ONE. (2013) 8:e55905. doi: 10.1371/journal.pone.0055905

81. El-Beshbishy HA, Aly HA, El-Shafey M. Lipoic acid mitigates bisphenol Ainduced testicular mitochondrial toxicity in rats. Toxicol Ind Health. (2013) 29:875-87. doi: 10.1177/0748233712446728

82. Abdel-Maksoud FM, Leasor KR, Butzen K, Braden TD, Akingbemi BT. Prenatal exposures of male rats to the environmental chemicals bisphenol a and $\mathrm{Di}(2$-Ethylhexyl) phthalate impact the sexual differentiation. Endocrinology. (2015) 156:4672-83. doi: 10.1210/en.2015-1077

83. Matthews JB, Twomey $\mathrm{K}$, Zacharewski TR. In vitro and in vivo interactions of bisphenol A and its metabolite, bisphenol A glucuronide, with estrogen receptors alpha and beta. Chem Res Toxicol. (2001) 14:14957. doi: 10.1021/tx0001833

84. Kuiper GG, Lemmen JG, Carlsson B, Corton JC, Safe SH, van der Saag PT, et al. Interaction of estrogenic chemicals and phytoestrogens with estrogen receptor beta. Endocrinology. (1998) 139:4252-63. doi: 10.1210/endo.139.10.6216

85. Alonso-Magdalena P, Ropero AB, Soriano S, García-Arévalo M, Ripoll C, Fuentes E, et al. Bisphenol-a acts as a potent estrogen via nonclassical estrogen triggered pathways. Mol Cell Endocrinol. (2012) 355:2017. doi: 10.1016/j.mce.2011.12.012

86. Nanjappa MK, Simon L, Akingbemi BT. The industrial chemical bisphenol A (BPA) interferes with proliferative activity and development of steroidogenic capacity in rat leydig cells. Biol Reprod. (2012) 86:135, 112. doi: 10.1095/biolreprod.111.095349
87. Ohlstein JF, Strong AL, McLachlan JA, Gimble JM, Burow ME, Bunnell BA. Bisphenol A enhances adipogenic differentiation of human adipose stromal/stem cells. J Mol Endocrinol. (2014) 53:345-53. doi: 10.1530/JME-14-0052

88. Masuno H, Kidani T, Sekiya K, Sakayama K, Shiosaka T, Yamamoto H, et al. Bisphenol A in combination with insulin can accelerate the conversion of 3T3-L1 fibroblasts to adipocytes. J Lipid Res. (2002) 43:676-84.

89. Marmugi A, Ducheix S, Lasserre F, Polizzi A, Paris A, Priymenko N, et al. Low doses of bisphenol A induce gene expression related to lipid synthesis and trigger triglyceride accumulation in adult mouse liver. Hepatology. (2012) 55:395-407. doi: 10.1002/hep. 24685

90. Legeay S, Faure S. Is bisphenol A an environmental obesogen? Fundam Clin Pharmacol. (2017) 31:594-609. doi: 10.1111/fcp.12300

91. Schneider G, Kirschner MA, Berkowitz R, Ertel NH. Increased estrogen production in obese men. J Clin Endocrinol Metab. (1979) 48:6338. doi: 10.1210/jcem-48-4-633

92. Bagatell CJ, Dahl KD, Bremner WJ. The direct pituitary effect of testosterone to inhibit gonadotropin secretion in men is partially mediated by aromatization to estradiol. J Androl. (1994) 15:15-21.

93. Giagulli VA, Kaufman JM, Vermeulen A. Pathogenesis of the decreased androgen levels in obese men. J Clin Endocrinol Metab. (1994) 79:9971000. doi: 10.1210/jcem.79.4.7962311

94. Isidori AM, Caprio M, Strollo F, Moretti C, Frajese G, Isidori A, et al. Leptin and androgens in male obesity: evidence for leptin contribution to reduced androgen levels. J Clin Endocrinol Metab. (1999) 84:367380. doi: $10.1210 /$ jc. 84.10 .3673

95. Caprio M, Isidori AM, Carta AR, Moretti C, Dufau ML, Fabbri A. Expression of functional leptin receptors in rodent Leydig cells. Endocrinology. (1999) 140:4939-47. doi: 10.1210/endo.140.11.7088

96. Darbre PD. Endocrine disruptors and obesity. Curr Obes Rep. (2017) 6:1827. doi: 10.1007/s13679-017-0240-4

97. Xu LC, Sun H, Chen JF, Bian Q, Qian J, Song L, et al. Evaluation of androgen receptor transcriptional activities of bisphenol a, octylphenol and nonylphenol in vitro. Toxicology. (2005) 216:197-203. doi: 10.1016/j.tox.2005.08.006

98. Sun H, Xu LC, Chen JF, Song L, Wang XR. Effect of bisphenol a, tetrachlorobisphenol a and pentachlorophenol on the transcriptional activities of androgen receptor-mediated reporter gene. Food Chem Toxicol. (2006) 44:1916-21. doi: 10.1016/j.fct.2006.06.013

99. Lee HJ, Chattopadhyay S, Gong EY, Ahn RS, Lee K. Antiandrogenic effects of bisphenol a and nonylphenol on the function of androgen receptor. Toxicol Sci. (2003) 75:40-6. doi: 10.1093/toxsci/kfg150

100. Wang H, Ding Z, Shi QM, Ge X, Wang HX, Li MX, et al. Anti-androgenic mechanisms of bisphenol a involve androgen receptor signaling pathway. Toxicology. (2017) 387:10-6. doi: 10.1016/j.tox.2017.06.007

101. McLachlan RI, O’Donnell L, Meachem SJ, Stanton PG, de Kretser DM, Pratis K, et al. Identification of specific sites of hormonal regulation in spermatogenesis in rats, monkeys, and man. Recent Prog Horm Res. (2002) 57:149-79. doi: 10.1210/rp.57.1.149

102. Anderson RA, Baird DT. Male contraception. Endocr Rev. (2002) 23:73562. doi: 10.1210/er.2002-0002

103. D'Cruz SC, Jubendradass R, Jayakanthan M, Rani SJ, Mathur PP. Bisphenol A impairs insulin signaling and glucose homeostasis and decreases steroidogenesis in rat testis: an in vivo and in silico study. Food Chem Toxicol. (2012) 50:1124-33. doi: 10.1016/j.fct.2011.11.041

104. Kabuto H, Hasuike S, Minagawa N, Shishibori T. Effects of bisphenol A on the metabolisms of active oxygen species in mouse tissues. Environ Res. (2003) 93:31-5. doi: 10.1016/S0013-9351(03)00062-8

105. Anjum S, Rahman S, Kaur M, Ahmad F, Rashid H, Ansari RA, et al. Melatonin ameliorates bisphenol A-induced biochemical toxicity in testicular mitochondria of mouse. Food Chem Toxicol. (2011) 49:284954. doi: 10.1016/j.fct.2011.07.062

106. Iida H, Maehara K, Doiguchi M, Mori T, Yamada F. Bisphenol A-induced apoptosis of cultured rat sertoli cells. Reprod Toxicol. (2003) 17:45764. doi: 10.1016/S0890-6238(03)00034-0

107. Qi S, Fu W, Wang C, Liu C, Quan C, Kourouma A, et al. BPA-induced apoptosis of rat sertoli cells through Fas/FasL and JNKs/p38 MAPK pathways. Reprod Toxicol. (2014) 50:10816. doi: 10.1016/j.reprotox.2014.10.013 
108. Qian W, Zhu J, Mao C, Liu J, Wang Y, Wang Q, et al. Involvement of CaMCaMKII-ERK in bisphenol A-induced sertoli cell apoptosis. Toxicology. (2014) 324:27-34. doi: 10.1016/j.tox.2014.06.001

109. Wang C, Fu W, Quan C, Yan M, Liu C, Qi S, et al. The role of Pten/Akt signaling pathway involved in BPA-induced apoptosis of rat Sertoli cells. Environ Toxicol. (2015) 30:793-802. doi: 10.1002/tox.21958

110. Wang C, Qi S, Liu C, Yang A, Fu W, Quan C, et al. Mitochondrial dysfunction and $\mathrm{Ca}^{2+}$ overload in injured Sertoli cells exposed to bisphenol A. Environ Toxicol. (2017) 32:823-31. doi: 10.1002/tox.22282

111. Miao M, Zhou X, Li Y, Zhang O, Zhou Z, Li T, et al. LINE-1 hypomethylation in spermatozoa is associated with Bisphenol A exposure. Andrology. (2014) 2:138-44. doi: 10.1111/j.2047-2927.2013.00166.x

112. Li D-K, Zhou Z, Miao M, He Y, Wang J, Ferber J, et al. Urine bisphenol-A (BPA) level in relation to semen quality. Fertil Steril. (2011) 95:625-30.e14. doi: 10.1016/j.fertnstert.2010.09.026

113. Goldstone AE, Chen Z, Perry MJ, Kannan K, Louis GMB. Urinary bisphenol A and semen quality, the LIFE study. Re-prod Toxicol. (2015) 51:713. doi: 10.1016/j.reprotox.2014.11.003

114. Lassen TH, Frederiksen H, Jensen TK, Petersen JH, Joensen UN, Main $\mathrm{KM}$, et al. Urinary bisphenol A levels in young men: association with reproductive hormones and se-men quality. Environ Health Perspect. (2014) 122:478-84. doi: 10.1289/ehp.1307309

115. Adoamnei E, Mendiola J, Vela-Soria F, Fernández MF, Olea N, Jørgensen $\mathrm{N}$, et al. Urinary bisphenol A concentrations are associated with reproductive parameters in young men. Environ Res. (2018) 161:12228. doi: 10.1016/j.envres.2017.11.002

116. Meeker JD, Ehrlich S, Toth TL, Wright DL, Calafat AM, Trisini AT, et al. Semen quality and sperm DNA damage in relation to urinary bisphenol A among men from an infertility clinic. Reprod Toxicol. (2010) 30:5329. doi: 10.1016/j.reprotox.2010.07.005

117. Knez J, Kranvogl R, Breznik BP, Vončina E, Vlaisavljević V. Are urinary bisphenol A levels in men related to semen quality and embryo development after medically assisted reproduction? Fertil Steril. (2014) 101:215-21. doi: 10.1016/j.fertnstert.2013.09.030

118. Vitku J, Heracek J, Sosvorova L, Hampl R, Chlupacova T, Hill M, et al. Associations of bisphenol A and polychlorinated biphenyls with spermatogenesis and steroidogenesis in two biological fluids from men attending an infertility clinic. Environ Int. (2016) 89-90:166-73. doi: 10.1016/j.envint.2016.01.021

119. Radwan M, Wielgomas B, Dziewirska E, Radwan P, Kałuzny P, Klimowska A, et al. Urinary bisphenol a levels and male fertility. Am J Mens Health. (2018) 12:2144-51. doi: 10.1177/1557988318799163

120. Chen M, Tang R, Fu G, Xu B, Zhu P, Qiao S, et al. Association of exposure to phenols and idiopathic male infertility. J Hazard Mater. (2013) 250-1:11521. doi: 10.1016/j.jhazmat.2013.01.061

121. Pollard SH, Cox KJ, Blackburn BE, Wilkins DG, Carrell DT, Stanford JB, et al. Male exposure to bisphenol A (BPA) and semen quality in the home observation of periconceptional exposures (HOPE) cohort. Reprod Toxicol. (2019) 90:82-7. doi: 10.1016/j.reprotox.2019.08.014

122. Mendiola J, Jørgensen N, Andersson A-M, Calafat AM, Ye X, Redmon $\mathrm{JB}$, et al. Are environmental levels of bisphenol A associated with reproductive function in fertile men? Environ Health Perspect. (2010) 118:1286-91. doi: 10.1289/ehp.1002037

123. World Health Organization (WHO). WHO Laboratory Manual for the Examination of Human Semen and Sperm-Cervical Mucus Interaction. New York, NY: Cambridge University Press (1999).

124. World Health Organization (WHO). WHO Laboratory Manual for the Examination and Processing of Human Semen, 5th edn. WHO Press: Geneva (2010).

125. Atkinson A, Roy D. In vitro conversion of environmental estrogenic chemical bisphenol a to DNA binding metabolite(s). Biochem Biophys Res Commun. (1995) 210:424-33. doi: 10.1006/bbrc.1995.1678

126. Wetherill YB, Akingbemi BT, Kanno J, McLachlan JA, Nadaf A, Sonnenschein C, et al. In vitro molecular mechanisms of bisphenol a action. Reprod Toxicol. (2007) 24:178-98. doi: 10.1016/j.reprotox.2007.05.010

127. Buck Louis GM, Sundaram R, Sweeney AM, Schisterman EF, Maisog J, Kannan K. Urinary bisphenol A, phthalates, and couple fecundity: the longitudinal investigation of fertility and the environment (LIFE) study. Fertil Steril. (2014) 101:1359-66. doi: 10.1016/j.fertnstert.2014.01.022

128. Dodge LE, Williams PL, Williams MA, Missmer SA, Toth TL, Calafat AM, et al. Paternal urinary concentrations of parabens and other phenols in relation to reproductive outcomes among couples from a fertility clinic. Environ Health Perspect. (2015) 123:665-71. doi: 10.1289/ehp.1408605

129. Hulak M, Gazo I, Shaliutina A, Linhartova P. In vitro effects of bisphenol A on the quality parameters, oxidative stress, DNA integrity and adenosine triphosphate content in sterlet (Acipenser ruthenus) spermatozoa. Comp Biochem Physiol C Toxicol Pharmacol. (2013) 158:6471. doi: 10.1016/j.cbpc.2013.05.002

130. Lukacova J, Jambor T, Knazicka Z, Tvrda E, Kolesarova A, Lukac N. Doseand time-dependent effects of bisphenol A on bovine spermatozoa in vitro. J Environ Sci Health A Tox Hazard Subst Environ Eng. (2015) 50:66976. doi: 10.1080/10934529.2015.1011963

131. Rahman MS, Kwon WS, Lee JS, Yoon SJ, Ryu BY, Pang MG. Bisphenol-A affects male fertility via fertility-related proteins in spermatozoa. Sci Rep. (2015) 5:9169. doi: 10.1038/srep09169

132. Singh RP, Shafeeque CM, Sharma SK, Pandey NK, Singh R, Mohan J, et al. Bisphenol A reduces fertilizing ability and motility by compromising mitochondrial function of sperm. Environ Toxicol Chem. (2015) 34:161722. doi: 10.1002/etc. 2957

133. Terasaka H, Kadoma Y, Sakagami H, Fujisawa S. Cytotoxicity and apoptosisinducing activity of bisphenol A and hydroquinone in HL-60 cells. Anticancer Res. (2005) 25:2241-7.

134. Lee S, Suk K, Kim IK, Jang IS, Park JW, Johnson VJ, et al. Signaling pathways of bisphenol A-induced apoptosis in hippocampal neuronal cells: role of calcium-induced reactive oxygen species, mitogen-activated protein kinases, and nuclear factor-kappa B. J Neurosci Res. (2008) 86:293242. doi: 10.1002/jnr.21739

135. Bontempo P, Mita L, Doto A, Miceli M, Nebbioso A, Lepore I, et al. Molecular analysis of the apoptotic effects of BPA in acute myeloid leukemia cells. J Transl Med. (2009) 7:48. doi: 10.1186/1479-58 76-7-48

136. Lin Y, Sun X, Qiu L, Wei J, Huang Q, Fang C, et al. Exposure to bisphenol A induces dysfunction of insulin secretion and apoptosis through the damage of mitochondria in rat insulinoma (INS-1) cells. Cell Death Dis. (2013) 4:e460. doi: 10.1038/cddis.2012.206

137. Qian W, Wang Y, Zhu J, Mao C, Wang Q, Huan F, et al. The toxic effects of bisphenol A on the mouse spermatocyte GC-2 cell line: the role of the $\mathrm{Ca}^{2+}$-calmodulin-Ca ${ }^{2+} /$ calmodulin-dependent protein kinase II axis. J Appl Toxicol. (2015) 35:1271-7. doi: 10.1002/jat.3188

138. Barbonetti A, Castellini C, Di Giammarco N, Santilli G, Francavilla S, Francavilla F. In vitro exposure of human spermatozoa to bisphenol A induces pro-oxidative/apoptotic mitochondrial dysfunction. Reprod Toxicol. (2016) 66:61-7. doi: 10.1016/j.reprotox.2016. 09.014

139. Grami D, Rtibi K, Selmi S, Jridi M, Sebai H, Marzouki L, et al. Aqueous extract of eruca sativa protects human spermatozoa from mitochondrial failure due to bisphenol A exposure. Reprod Toxicol. (2018) 82:10310. doi: 10.1016/j.reprotox.2018.10.008

140. Francavilla F, Barbonetti A, Necozione S, Santucci R, Cordeschi G, Macerola B, et al. Within-subject variation of seminal parameters in men with infertile marriages. Int $J$ Androl. (2007) 30:174-81. doi: 10.1111/j.1365-2605.2006.00727.x

Conflict of Interest: The authors declare that the research was conducted in the absence of any commercial or financial relationships that could be construed as a potential conflict of interest.

Copyright (c) 2020 Castellini, Totaro, Parisi, D’Andrea, Lucente, Cordeschi, Francavilla, Francavilla and Barbonetti. This is an open-access article distributed under the terms of the Creative Commons Attribution License (CC BY). The use, distribution or reproduction in other forums is permitted, provided the original author(s) and the copyright owner(s) are credited and that the original publication in this journal is cited, in accordance with accepted academic practice. No use, distribution or reproduction is permitted which does not comply with these terms. 